Ottar Sjaastad

Torbjörn A. Fredriksen

Jan Båtnes

Hans C. Petersen

Leiv S. Bakketeig

\section{Whiplash in individuals with known pre-accident, clinical neck status}

Received: 25 November 2005

Accepted in revised form: 31 January 2006

Published online: 20 February 2006

O. Sjaastad

Department of Neurology,

St Olavs Hospital,

Trondheim University Hospitals (NTNU),

Trondheim, Norway

O. Sjaastad • J. Båtnes

Vågå Communal Health Centre,

Vågåmo, Norway

\section{T.A. Fredriksen}

Department of Neurosurgery,

St Olavs Hospital Trondheim,

Trondheim University Hospitals (NTNU),

Trondheim, Norway

H.C. Petersen

Department of Statistics,

University of Southern Denmark,

Odense, Denmark

\section{L.S. Bakketeig}

IST Institute of Public Health,

Epidemiology,

Søndre Boulevard 23a,

DK-5000 Odense C, Denmark

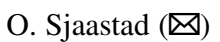

Gautes gate 12,

N-7030 Trondheim, Norway

e-mail: berit.mjoen@medisin.ntnu.no

Tel: +47-73-525276

Fax: +47-73-551539
Abstract In whiplash studies, there may be interpretation difficulties: are post-whiplash findings, when present, a consequence of the whiplash trauma, or did they exist prior to trauma? In the Vågå headache epidemiology study (1995-1997), there was a headache history and detailed physical/neurological findings from the face/head/neck in1838 18-65-yearold parishioners. In September 2001, four years after the Vågå study, a search through the Health Centre files divulged six cases with whiplash trauma in the intervening period. These parishioners could thus be their own controls. Two females did not develop new complaints. In the four parishioners with apparently new, subjective complaints, i.e., headache, neck pain, and a feeling of stiffness in the neck, there were corresponding findings as regards various parameters: shoulder area skin-roll test, changes in two, possible changes in two; range of motion, neck, changes in two, borderline changes in one; "features indicative of cervical abnormality" ("CF"), changes in all four; the mean, post-whiplash stage value was: $3.6+$, against $1.6+$ prior to accident (Vågå: only $0.93 \%$, "CF" exceeding 3+). In the two without new complaints, the mean "CF" value was $1.0+$. The number of cases is small, but the similarity of the symptoms - and signs - following whiplash injury may suggest an element of organic origin in the whiplash syndrome.

Keywords Headache - Whiplash • Neck sprain - Skin-roll test • Mechanical precipitation of headache 


\section{Introduction}

The so-called late whiplash syndrome is characterised by a certain constellation of symptoms: mainly neck ache, subjective feeling of neck stiffness and headache, persisting in excess of 6 months after, mostly rear-end, car collisions. Grossly, the medical world is divided into two factions in its view of the late whiplash syndrome. One faction ascribes the complaints largely to a particular mental attitude towards putative economic compensation [e.g., 1-3]. The other faction has it that organic, cervical changes are more likely to some extent to underlie the symptoms [4, 5]. Clinical neurological examination has not uncovered consistent neck abnormalities [1]. This can, however, not be taken as hard evidence that the firstmentioned faction is right. A well known, inherent shortcoming of whiplash studies in general is the interpretation difficulty: are headache/neck problems and/or neurological findings due to the trauma, or were they preexisting?

During the Våga study of headache (October 1995-September 1997) [6], a face-to-face interview and a neurological/physical examination of the head and neck [7] were incorporated. In September 2001, 4-6 years after the Vågå study, the files of the Vågå Health Centre were scanned for whiplash cases. Probably, some parishioners would have sustained an indirect neck trauma in the intervening period. This proved to be the case.

The principal aim of this study was, accordingly, on the basis of pre- and post-injury examinations, to search for physical/neurological findings and symptoms, mainly headache and its attributes, possibly originating in the post-whiplash period.

\section{Material and methods}

There were 3907 parishioners in Våga in 1995, just prior to the start of the Våga study. All 18-65-year-old parishioners were invited to participate, and 1838 of those available (88.6\%) were examined by the principal investigator (O. Sjaastad) [7]. The examination included a detailed survey of headache problems in a face-to-face interview, based on an elaborate questionnaire. A routine, detailed physical/neurological examination of the face, head, and neck was carried out, and, in addition, a short-version general, neurological examination (examination I). A special, clinical examination programme [8,9], elaborated upon in the forthcoming, "features indicative of cervical abnormality", was included. If deemed necessary from a clinical point of view, a full-scale neurological examination was carried out. In such cases, X-ray examination and CT/MR examinations of the head/neck might also be carried out. Minor, possible abnormalities on neurological examination (changes at the "academic level") were not taken into account.
Table 1 Whiplash syndrome criteria. Features 5-7 are probably the main constituents of the whiplash injury symptomatology

1. Evidence for indirect neck trauma of the hyperextension/hyperflexion type $\mathrm{e}^{\mathrm{a}, \mathrm{b}, \mathrm{c}}$

2. Trauma of a severity leading to consultation (in our context) a $^{\mathrm{a}, \mathrm{b}}$

3. No symptoms and signs caused by additional head injury ${ }^{b}$

4. No loss of consciousness in connection with trauma ${ }^{b}$

5. Neck pain ${ }^{\mathrm{a}, \mathrm{b}}$

6. Headache ${ }^{\mathrm{a}, \mathrm{b}, \mathrm{c}}$

7. Subjective feeling of neck stiffness

8. Symptoms (headache in our context), developing within 3 days ${ }^{b}$

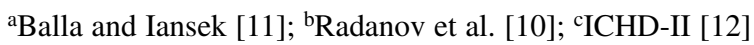

In September 2001, 4-6 years later, the files of the Vågå Communal Health Centre were scrutinised for neck sprain cases occurring after examination I. This resulted in the retrieval of six records from parishioners with probable whiplash trauma, sufficiently severe to have led to consultation, each parishioner thereby implicitly acknowledging being a patient. There was thus already at the outset a selection: these whiplash victims seemed to have exacerbations/de novo symptoms. These parishioners were then examined (examination II).

The whiplash criteria of the IHS were not available at the time. Criteria were, therefore, constructed (Table 1); they were mainly based on Radanov and co-workers' criteria [10], but also contain elements from Balla \& Iansek's work [11] and - later proved to contain elements also from the ICHD-II [12]. To diagnose cervicogenic headache $(\mathrm{CEH})$, the CHISG criteria at the time were adhered to [13]. Migraine and tension-type headaches were diagnosed according to the IHS criteria [14].

Assessment of the methods used: "features indicative of cervical abnormality" [8]

A crucial component of this study is the pre-whiplash physical examination, which comprised the following five factors: (I) skin-roll test; (II) provocation of pain from (a) neck muscles, (b) tendons in the neck/occipital area and (c) facet joints; and (III) range of motion in the neck. I-III were collectively termed: "features indicative of cervical abnormality" or "CF". Another basic feature of the Vågå study was the blinded re-investigation of 41 ( 39) randomly selected parishioners concerning "CF" after a mean of 14.8 months (range 4-23). One could then also assess the spontaneous changes in these variables over time.

Skin-roll test [10, 16]

Shoulder "arch" skin-roll test consists of two parts: tenderness and skinfold thickness measurements. For these measurements, we used callipers (Servier ${ }^{\circledR}$, Leiden). Crucial control values in the general population and headache-free individuals are recorded in Table 2 . The reliability of this test has been assessed in two ways. Immediate reproducibility ( $n=1796$ parishioners, with 3592 mea- 
Table 2 The assessment system. A rough overview

\begin{tabular}{|c|c|c|c|c|c|c|c|c|}
\hline \multirow{2}{*}{$\begin{array}{l}\text { Pertinent } \\
\text { variable }\end{array}$} & \multirow{2}{*}{$\begin{array}{l}\text { "Cervical } \\
\text { features" } \\
(\text { "CF") } \\
(0-5.0+)^{\mathrm{a}} \\
\text { Vågå study }\end{array}$} & \multicolumn{3}{|c|}{ Provocation of head pain from: } & \multirow{2}{*}{$\begin{array}{l}\text { Provocation; total } \\
(0-2.5+)\end{array}$} & \multirow{2}{*}{$\begin{array}{l}\text { Skin-roll } \\
\text { test }(\mathrm{mm}) \\
(0-1.0+)\end{array}$} & \multirow{2}{*}{$\begin{array}{l}\text { ROM } \\
\text { (Rotation } \\
\text { deficit in }^{\circ} \text { ) } \\
(0-1.0+)\end{array}$} & \multirow{2}{*}{$\begin{array}{l}\text { Intensity } \\
\text { grading } \\
(0-6+[24])\end{array}$} \\
\hline & & $\begin{array}{l}\text { Neck } \\
\text { muscles } \\
(0-0.5+)\end{array}$ & $\begin{array}{l}\text { Occipital } \\
\text { tendons } \\
(0-1.5+)\end{array}$ & $\begin{array}{l}\text { Facet } \\
\text { joints } \\
(0-0.5+)\end{array}$ & & & & \\
\hline $\begin{array}{l}\text { General } \\
\text { population, } \\
\text { mean }^{\mathrm{b}}\end{array}$ & 0.79 & - & - & - & $0.15+$ & $15.1 \pm 6.0$ & - & 2.8 \\
\hline $\begin{array}{l}\text { Definite } \\
\text { abnormality }\end{array}$ & $\begin{array}{l}>3.0: 0.93 \% \\
>2.5: 2.3 \% \\
>2.0: 6 \%\end{array}$ & 0.5 & $0.5(1.0 ?)$ & 0.5 & $>0.5$ & $\geq$ ca. 25 & - & $\geq 2.0$ \\
\hline $\begin{array}{l}\text { HA-free } \\
\text { group, mean }\end{array}$ & 0.42 & 0.006 & 0.002 & 0.002 & $\begin{array}{l}0.01 \\
\geq 0.5 \\
(1.6 \% \text { of all cases })\end{array}$ & $14.3 \pm 5.7$ & $\begin{array}{l}6.2 \\
\text { (range: } 0-75)\end{array}$ & NR \\
\hline $\begin{array}{l}\text { Change } \\
\text { with time } \\
\text { mean }\end{array}$ & 0.17 & - & 0.05 & 0.01 & 0.065 & $\begin{array}{l}2.3(>5, \text { ca. } 6 \% \\
\text { of the observations })^{\mathrm{e}}\end{array}$ & 5.2 & 0.2 \\
\hline $\begin{array}{l}\text { Maximum } \\
\text { change } \\
\text { observed }\end{array}$ & $1.0(7.7 \%)$ & $0.5^{\mathrm{f}}$ & $0.5^{\mathrm{f}}$ & $0.5^{\mathrm{f}}$ & $1.0^{\mathrm{f}}$ & $9^{e}$ & 20 & 1.0 \\
\hline $\begin{array}{l}\text { Asymmetry, } \\
\text { abnormal }\end{array}$ & NR & 0.5 & 0.5 & 0.5 & $0.5 ?$ & $\begin{array}{l}>3 \text { (in } 6.1 \% \\
\text { of the cases) }\end{array}$ & $\geq 10$ & NR \\
\hline
\end{tabular}

aFeatures indicative of cervical abnormality [9]. The sum is actually $4.5+(2.5+$ (pain provocation); $1.0+$ (skin-roll test), and 1.0+ (ROM).

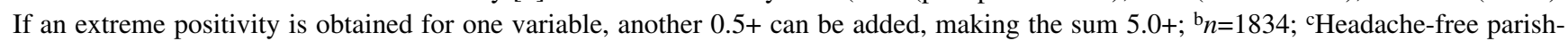
ioners; $n=246$; 39 parishioners examined prior to and after a mean interval of 14.8 months (range 4-23 month); eIn all observations with a change of $\geq 4 \mathrm{~mm}$, a reduction - not an increase - of skin-fold thickness had taken place; ${ }^{\mathrm{f}} \mathrm{A}$ reduction had taken place $N R$, not relevant.

surements on each side). The measurement error exceeded $2 \mathrm{~mm}$ in $4.4 \%$ of the cases and $3 \mathrm{~mm}$ in $1.1 \%$ of the cases. Measurements after a mean respite of 14.8 months $(n=41 \sim 40$, Vågå study) (Table 2) [7]. In cases with a change of $\geq 4 \mathrm{~mm}$ over time, there was invariably a reduction of thickness. The highest increment observed was $3 \mathrm{~mm}$ (in $1.3 \%$ of the observations). Absolute values $\geq 25 \mathrm{~mm}$ are considered pathological. An asymmetry of $>3 \mathrm{~mm}$ will strengthen the notion of abnormality, even with both the first and second measurement results within the control range, i.e. $<25 \mathrm{~mm}$. Tenderness was estimated by personal judgement: "0" = no or "normal" tenderness; " $0.5+$ " = "considerable", i.e., increased tenderness. The total test result was graded: $0.5+$, either increased skinfold thickness or considerable tenderness; $1.0+$, positivity with regard to both components. Changes in tenderness as such over time are difficult to assess, because of lack of adequate guidelines. Tenderness asymmetry at a given time is a variable that lends itself to semi-quantification.

\section{Provocation of pain}

This section actually consists of three solitary parts, a-c (Table 2 ). The basic idea is to precipitate a head pain exacerbation or even an attack. One has tried to achieve this by: (a) external pressure over the neck muscles (upper part of $\mathrm{m}$. trapezius, $\mathrm{m}$. splenius and m. sternocleidomastoideus); (b) pressure over the tendons in the occipital area and (c) pressure over the facet joints. The digital pressure applied was graded in three principal steps: mild, $0.5-1.0 \mathrm{~kg}$; moderate, $3-4 \mathrm{~kg}$; and hard pressure, 6-8 kg. Much emphasis has been placed on the response to 3-4 $\mathrm{kg}$ : the force used for identifying trigger points in fibromyalgia: $4 \mathrm{~kg}[16,17]$. The responses were graded [8]. Test (b) was assessed in this way: no - or minor - local discomfort, 0 ; discomfort spreading to the upper occipital area, 0.5+; discomfort/pain spreading to the frontal area, 1.0+; and long-lasting, frontal pain, 1.5+. For tests (a) and (c), the top grade was $0.5+$, which involved spreading of pain to the anterior area. The contribution of these three precipitation factors thus amounted to a totality of $2.5+$. In headache-free individuals in Vågå $(n=246)$, the sum of the provocation factors was minute, i.e., $0.01+$, on average (Table 2). The mean change in these provocation mechanisms over 14.8 months was a minor one. Only in four cases could a change be observed (in three, $0.5+$ and in one, $1.0+$ ), and invariably a reduction was found.

Range of motion in the neck (ROM) - rotation

Only rotation was checked, as it is the easiest movement to assess visually, in our estimation. Passive rotation in the sitting 
position was assessed by a trained observer [11], in steps of $5^{\circ}$ or $5^{\circ}-10^{\circ}$ (control values, Table 2) [8]. Immediate reproducibility was satisfactory, i.e., with an error of $<10^{\circ}$. Even when following 41 parishioners over a mean of 14.8 months, a blinded re-assessment showed fairly good correspondence. Changes in excess of $10^{\circ}$ over such time can probably generally be detected with this rough method. Rotation capacity reduction: $0.5+$ signifies $\geq 10^{\circ}-\leq 20^{\circ}$ reduction. A reduction $\geq 25^{\circ}$ was given the mark $1.0+$.

\section{Total score}

A total score of $4.5+$ can accordingly be arrived at for CF. The score for one of the solitary components can, in case of extreme positivity, be increased by a $0.5+$ value, rendering an absolute maximum of $5.0+[8]$ (Table 2).

\section{Intensity assessment}

A sensitive 0-6+ grading system was used for headache intensity assessment [19]. In this grading: 1+ means "minimal unpleasantness", i.e., without procrastination; $2+$ means "heaviness/discomfort", i.e., influence upon social life; $3+$, "mild"; 4+, "moderate"; 5+, "severe"; and 6+, "excruciatingly severe pain"; steps $3+-5+$ correspond to the steps in the IHS grading, carrying the same designations [14].

\section{Control studies}

Neck ache [19] and headache [20] are frequently occurring complaints in the population at large. Therefore, it would have been necessary to include a control group, unexposed to whiplash, if the issue were the absolute extent of the head- and/or neck ache in a whiplash group. The aim in our study is a different one: to search for minor changes in a few whiplash cases (case history/clinical findings), where each one served as his/her own control. Moreover, the values for $\mathrm{CF}$, etc. in the whiplash group could be compared to the control values from the Våga study, i.e., from the same population. As ROM assessment may be a critical factor in $\mathrm{CF}$, for each of the patients, one or more ageand sex-matched controls have been chosen blindly from the headache-free group ( $n=246)$ in the Vågå study.

This study has been accepted by the Regional Ethics Committee and State Data Inspectorate.

\section{Results}

Five females and one male had sustained a whiplash trauma, the mean age at examination II being 45 years (range 26-60) (Table 3). Four of them fulfilled the criteria for the whiplash syndrome (Table 1). Two of them did not develop a protracted neck- and headache (Table 3). Our four patients seemed to belong to category WAD II, according to the Quebec whiplash classification [2]. Only the most heavily affected whiplash victim (case 4) had a chronic, fluctuating post-whiplash headache.

\section{Examination I}

All six had one headache (or more) diagnosed at examination I - prior to whiplash (see also [10]). Most of them

Table 3 Pre-whiplash headache

\begin{tabular}{|c|c|c|c|c|c|}
\hline \multirow[b]{2}{*}{ Case no. } & \multirow[b]{2}{*}{ Sex } & \multicolumn{2}{|c|}{ Headache prior to whiplash } & \multicolumn{2}{|r|}{ Age } \\
\hline & & Diagnosis & Age at onset (years) & At whiplash (years) & At examination II (years) \\
\hline 1 & $\mathrm{~F}$ & $\begin{array}{l}\text { I M-A } \\
\text { II T-TH }\end{array}$ & $\begin{array}{l}\text { I: } 13 \\
\text { II: ? }\end{array}$ & 23 & 26 \\
\hline 2 & $\mathrm{~F}$ & $\begin{array}{l}\text { I M-A } \\
\text { II Supraorb. neuralgia }\end{array}$ & $\begin{array}{l}\text { I: } 10 \\
\text { II: } 25\end{array}$ & 56 & 58 \\
\hline 3 & M & $M-A^{a}$ & Teens & 58 & 60 \\
\hline 4 & $\mathrm{~F}$ & CEH (?) after whiplash $\mathrm{I}^{\mathrm{b}}$ & 20 & 26 & 31 \\
\hline 5 & $\mathrm{~F}$ & $\mathrm{M}-\mathrm{A}^{\mathrm{c}}$ & $\leq 10$ & 36 & 40 \\
\hline 6 & $\mathrm{~F}$ & $\begin{array}{l}\mathrm{M}+\mathrm{A} \\
\text { Transformed migraine }\end{array}$ & $\begin{array}{l}<15 \\
\text { ca. } 40\end{array}$ & 55 & 56 \\
\hline
\end{tabular}

$M \pm A$, migraine \pm aura; $T$ - $T H$, tension-type headache; $C E H$, cervicogenic headache

The interrupted, horizontal line is drawn between those who did not acquire (cases 1 and 2) and those who acquired (cases 3-6) a de novo headache or an exacerbation of existing headache after the whiplash trauma

a Last year prior to examination I: rare headache attacks. Analgesics, 3-4 times/year; beadache clearly diminishing with time after whiplash I, which took place 3 years prior to examination I. Last year prior to examination I: no appreciable headache/neck ache; ${ }^{c}$ Prior to whiplash: 6-20 attacks per year. After accident: more or less daily headache, though improvement last year; $50 \%$ job 
suffered from migraine from a young age. In one of them (case 4), there seemed to have been CEH of mild-moderate intensity (Table 3). Upon physical examination (Table 4), there were some borderline/slightly pathological findings; thus, ROM: in case 3; precipitation of discomfort/headache: case 1 (who did not develop new headache) and case 4 . None of the four affected ones seemed to have had subjective neck complaints just prior to the whiplash episode. The mean interval between examination I and the neck sprain was approximately 2 years (range 0-4.5 years) and between whiplash and examination II: 2.8 years.

The whiplash injury

According to rough estimates made by the traffic accident victims themselves, the mean "speed difference" was around $55 \mathrm{~km} / \mathrm{h}$ (case 2 not included, Table 5). The whiplash victim was the driver, with one exception. In four cases, there was a rear-end collision. Direct face, head or neck trauma, leading to additional injury, occurred in none of the cases. Consciousness was not altered (Table 1).
Post-whiplash complaints: head- and neck ache

The post-whiplash examination II was carried out absolutely blindly. All six got neck ache/stiffness in the neck with an early onset; in cases 1 and 2, it was only transitory. In those with persistent problems, neck symptoms seemed mostly to be ipsilateral to the headache (Table 6).

A de novo headache or exacerbation of a pre-existing one was found in four cases (cases 3-6) (Tables 3 and 6). De novo headache and "old" headache could co-exist, e.g., case 6 . In case 5 , frequency/localisation of the recent headache were at variance with those of the migraine attacks; the hemicranial discomfort was new. Or: the "old" headache had lost much of its punch at the time of whiplash, e.g., case 3, and what was left seemingly was replaced by another headache, with e.g., bilaterality and precipitation of attacks (Table 4), different pain characteristics (Tables 3, 6-8) and frequency. An augmentation of a pre-existing, rather moderate $\mathrm{CEH}$ (actually dormant at the time of accident) might also occur (case 4, Tables 3, 6 and 7). In three of the four cases, there was a unilateral/predominantly unilateral headache (Table 6). There did not seem to be any marked increment in intensity from examination I (mean $3.5+$ ) to examination II

Table 4 The various components of "CF", examinations I and II, and laterality

\begin{tabular}{|c|c|c|c|c|c|c|c|}
\hline \multirow[t]{2}{*}{ Case } & \multirow{2}{*}{$\begin{array}{l}\text { Examinations } \\
\text { I/II }\end{array}$} & \multicolumn{2}{|c|}{ Neck rotation (ROM) } & \multirow{2}{*}{$\begin{array}{l}\text { Skinfold } \\
\text { thickness } \\
(\mathrm{mm}) \mathrm{R} / \mathrm{L}\end{array}$} & \multirow{2}{*}{$\begin{array}{l}\text { Provocations, } \\
\text { head pain } \\
\left(0-2.5+(3.0+)^{\mathrm{b}}\right.\end{array}$} & \multicolumn{2}{|c|}{ Present stage } \\
\hline & & $\begin{array}{l}\text { Whiplash cases: } \\
\text { deficit in }{ }^{\circ}(\mathrm{R} / \mathrm{L})\end{array}$ & $\begin{array}{l}\text { Patient controls: } \\
\text { deficit in }{ }^{\circ}(\mathrm{R} / \mathrm{L})^{\mathrm{a}}\end{array}$ & & & $\begin{array}{l}\text { Side } \\
\text { preponderance, } \\
\text { provocation tests }\end{array}$ & $\begin{array}{l}\text { Head pain } \\
\text { side }\end{array}$ \\
\hline \multirow[t]{2}{*}{1} & I & $5-10 / 0$ & $0 / 0$ & $10 / 12$ & 1.5 & \multirow[b]{2}{*}{ NR } & \multirow[b]{2}{*}{ NR } \\
\hline & II & & & $11 / 13$ & & & \\
\hline \multirow[t]{3}{*}{2} & $\mathrm{I}$ & $5-10 / 5-10$ & $10-15 /$ & $12 / 13$ & 0 & \multirow{3}{*}{ NR } & \multirow{3}{*}{ NR } \\
\hline & & & $10-15$ & & & & \\
\hline & II & $15 / 15-20$ & & $12 / 13$ & 0 & & \\
\hline \multirow[t]{3}{*}{3} & $\mathrm{I}$ & $15 / 15$ & $15 / 15$ & $17 / 16$ & 0.5 & \multirow{3}{*}{$\mathrm{R}=\mathrm{L}$} & \multirow{3}{*}{$\mathrm{R}=\mathrm{L}$} \\
\hline & & & & & & & \\
\hline & II & $45 / 35-40$ & & $19 / 20$ & 1.5 & & \\
\hline \multirow[t]{3}{*}{4} & I & $10 / 5$ & $0 / 0$ & $21 / 18$ & 2.0 & \multirow{3}{*}{$\mathrm{R}>\mathrm{L}$} & \multirow{3}{*}{$\mathrm{R}$} \\
\hline & & & & & & & \\
\hline & II & $30 / 15$ & & $33 / 27$ & 3.0 & & \\
\hline \multirow[t]{3}{*}{5} & $\mathrm{I}$ & $0 / 0$ & $15 / 15$ & $7 / 8$ & 0 & \multirow{3}{*}{$\mathrm{R}>\mathrm{L}$} & \multirow{3}{*}{$\mathrm{R}>\mathrm{L}$} \\
\hline & & & & & & & \\
\hline & II & $0 / 5-10$ & & $16 / 15$ & 1.0 & & \\
\hline \multirow[t]{3}{*}{6} & I & $5 / 10$ & $15 / 15$ & $\mathrm{c} ?$ & 0.5 & \multirow{3}{*}{$\mathrm{R}$} & \multirow{3}{*}{$\mathrm{R}$} \\
\hline & & & & & & & \\
\hline & II & $15 / 10$ & & $31 / 32$ & 2.5 & & \\
\hline
\end{tabular}

aSee text; there was one single age- and sex-matched and headache-free control for each case, except for case $3\left(n=6\right.$; range $\left.0-40^{\circ}\right)$ and

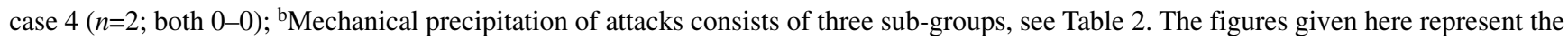
sum of the solitary subgroups; ' $T$ Technically unsuccessful $N R$, not relevant; $R / L$, right and left sides 
Table 5 Traffic accidents: specific traits

\begin{tabular}{|c|c|c|c|c|c|}
\hline Case & $\begin{array}{l}\text { Mode of accident. } \\
\text { Rear-end hit }+/-\end{array}$ & $\begin{array}{l}\text { Speed difference } \\
\text { between cars }(\mathrm{km} / \mathrm{h})^{\mathrm{a}}\end{array}$ & $\begin{array}{l}\text { Neck support/seat belt, } \\
\text { at the time of impact }\end{array}$ & $\begin{array}{l}\text { Write off (W-o)/repair } \\
(\mathrm{R}) \text { of car }\end{array}$ & In driver's seat \pm \\
\hline 1 & + & $60-70$ & Poor/+ & $\mathrm{R}$ & + \\
\hline 2 & $\mathrm{~b}, \mathrm{c}$ & $--^{\mathrm{b}, \mathrm{d}}$ & $+/+$ & W-o & + \\
\hline 3 & + & $40+(?)$ & $+/+$ & $\mathrm{R}$ & + \\
\hline 4 & $+^{\mathrm{e}}$ & $40-50$ & $-1-$ & $\mathrm{R}$ & $-_{-}^{\mathrm{f}}$ \\
\hline 5 & $\mathrm{~b}$ & $40-50$ & $+/+$ & $\mathrm{R}$ & + \\
\hline 6 & + & 80 & Poor/+ & W-o & + \\
\hline
\end{tabular}

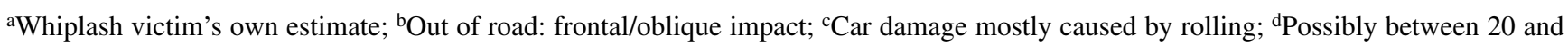
$30 \mathrm{~km} / \mathrm{h}$. Due to the special circumstances, more uncertain information as regards velocity than for cases 1 and 3-6; ' Series of collisions, combined rear-end and frontal impact; ${ }^{\text {PPassenger, back seat }}$

No one involved in litigation process

Table 6 Headache and neck ache after whiplash

\begin{tabular}{|c|c|c|c|c|c|c|c|c|c|c|}
\hline \multirow[t]{2}{*}{ Case } & \multicolumn{4}{|c|}{ De novo headache } & \multirow{2}{*}{$\begin{array}{l}\text { Original HA; } \\
\text { localisation }\end{array}$} & \multicolumn{5}{|c|}{ Neck ache } \\
\hline & $\begin{array}{l}\text { From } \\
\text { when? }\end{array}$ & Duration & Grade $^{a}$ & Localisation & & $+/-$ & $\begin{array}{l}\text { From } \\
\text { when? }\end{array}$ & Localisation & Duration & Dizziness \\
\hline 1 & - & - & No extra HA & - & - & + & Same day & $\mathrm{R}$ & $1-2$ weeks & - \\
\hline 2 & - & - & No extra HA & - & - & + & Next day & Bilateral (?) & $\begin{array}{l}\text { Couple } \\
\text { weeks }\end{array}$ & - \\
\hline 3 & $\begin{array}{l}\text { Next } \\
\text { day }\end{array}$ & $\begin{array}{l}\text { Lasting; } \\
\text { recent } \\
\text { improvement }\end{array}$ & 4 & $\begin{array}{l}\text { Bilateral } \\
\mathrm{O} \rightarrow \mathrm{T}\end{array}$ & $\mathrm{R}>\mathrm{L}^{\mathrm{c}} ; \mathrm{F}$ & + & Next day & Bilateral & Lasting & $+(?)$ \\
\hline 4 & $\begin{array}{l}\text { Same } \\
\text { day }\end{array}$ & $\begin{array}{l}\text { Chronic } \\
\text { fluctuating } \\
\text { course }^{\mathrm{d}}\end{array}$ & $4-5$ & $\mathrm{R}$ & $\mathrm{R}>\mathrm{L}$ & + & Same day & $\mathrm{R}$ & Lasting & $+\rightarrow-$ \\
\hline 5 & $\begin{array}{l}\text { Slightly } \\
\text { after } \\
\text { onset } \\
\text { neck } \\
\text {-ache (?) }\end{array}$ & Lasting & $3-4$ & $\begin{array}{l}\mathrm{R}>\mathrm{L} \\
\mathrm{O} \rightarrow \mathrm{F}\end{array}$ & $\mathrm{R}>\mathrm{L} ; \mathrm{F}$ & + & Next day & $\mathrm{R}$ & Lasting & $+(?)$ \\
\hline 6 & $\begin{array}{l}\text { Next } \\
\text { day }\end{array}$ & Lasting & 4 & $\mathrm{R}: \mathrm{O} \rightarrow \mathrm{T}$ & $\mathrm{R}$ & + & Next day & $\mathrm{R}(?)$ & Lasting & + \\
\hline
\end{tabular}

$F$, frontal area; $O$, occipital area; $T$, temporal area; $R$, right side; $L$, left side; $H A$, headache

aHeadache grading: 0-6+ (see text); ${ }^{\text {b} A f t e r ~ w h i p l a s h: ~ w h o l l y / p a r t l y ~ o u t ~ o f ~ w o r k ~ f o r ~ s e v e r a l ~ m o n t h s ; ~ a n a l g e s i c s: ~ a ~ 10-f o l d ~ i n c r e a s e ; ~}{ }^{\mathrm{C}}$ With side shift of pain; ${ }^{\mathrm{d}}$ No influence of two post-whiplash II pregnancies upon headache, a feature counting strongly against migraine [31]; No signs of fibromyalgia [16, 17]. Neurological examination: neg

Recently, 1 year sick leave. Now: $70 \%$ work.

MR neck, 1.5 y after examination II: neg

(mean 4.0+) (Table 7). The main difference seemed to be the tendency to protractedness. In one case (case 5), the intensity might even have diminished (Table 7), while the persistence dominated the picture (Table 3 ). All four could provoke an exacerbation/headache attack by awkward neck movements (Tables 4 and 8).
Unilateral pain is typical of both migraine and CEH. There might also be a pulsatile component of the pain at the peak of pain. The affected ones could, nevertheless, easily separate the "new" from the "old" variety of headache. Migraine was not a serious, diagnostic alternative for the new variety in any of the cases. There were 
Table 7 Changes between examinations I and II. Summary of findings

\begin{tabular}{llllll}
\hline Case & $\begin{array}{l}\text { Skin-fold } \\
\text { thickness. } \\
\text { Changes R/L (mm) }\end{array}$ & $\begin{array}{l}\text { Tenderness, } \\
\text { skin-roll test. } \\
\text { Changes R/L (0-0.5+) }\end{array}$ & $\begin{array}{l}\text { ROM. Changes } \\
\text { in rotation: } \\
\text { R/L; in degrees; deficits }\end{array}$ & $\begin{array}{l}\text { Mechanical } \\
\text { precipitation } \\
(0-2.5+)\end{array}$ & $\begin{array}{l}\text { Grading of headache } \\
\text { intensity. } \\
\text { Previous/present }(0-6+)^{\mathrm{a}}\end{array}$ \\
\hline 1 & $1 / 1$ & $0 / 0$ & $0 /<10$ & 0 & $2-3 / 2-3$ \\
2 & $0 / 0$ & $0 / 0$ & $<10 / 10$ & 0 & $3 / 3$ \\
3 & $2 / 4$ & $0 / 0$ & $30 / 20$ & 1.0 & $2-4 / 4$ \\
4 & $12 / 9$ & $0 / 0$ & $5 / 25$ & 1.0 & $3-4$ b/4-5 \\
5 & $9 / 7$ & $0 / 0.5$ & $0 /<10$ & 1.0 & $4-5 / 3-4$ \\
6 & 9 & $0 / 0$ & $10 / 0$ & 2.0 & $3 / 4$
\end{tabular}

${ }^{a}$ Grading according to a scale 0-6+ [19]. The average headache intensity did not change much from prior to (average 3.5+) to after whiplash (average 4.0+). It was more the frequency/persistence of the headache that changed; bFirst period after whiplash injury I. Later, between whiplash I and II: no appreciable neck ache/headache (not shown in the table); ${ }^{c}$ No examination I result. Examination II: $31 / 32$ $\mathrm{mm}$, which are values outside the normal range $(<25 \mathrm{~mm})$

"Mechanical precipitation" is a summation factor, i.e., external pressure against: (A) neck muscles; (B) tendons, occipital area; (C) facet joints (see Tables 2 and 9)

Table 8 CEH criteria: cases of de novo headache or worsening of headache $(n=4)$

\begin{tabular}{lllll}
\hline CEH criteria & \multicolumn{4}{c}{ Case no. } \\
\cline { 2 - 5 } & 3 & 4 & 5 & 6 \\
\hline Unilaterality of pain & - & + & $(+)^{\mathrm{a}}$ & + \\
$\begin{array}{l}\text { Provocation of pain/attacks: } \\
\quad \text { Subjectively }\end{array}$ & + & + & + & + \\
$\quad$ Objectively & + & + & + & + \\
Ipsilateral shoulder/arm pain & $++^{\mathrm{b}} ?$ & + & + & + \\
ROM reduction & + & + & - & + \\
\hline
\end{tabular}

aUnilateral preponderance

bProbably minor discomfort upon coughing

definite, ipsilateral, upper extremity complaints in three of them (Table 8), the quality being "shooting"/“vague", or more like paraesthesias.

Physical findings after whiplash injury

The results of the three main components making up CF are detailed in Table 4. The provocation factor, actually consisting of three solitary sub-factors (Table 2), was unchanged in the two asymptomatic parishioners. In cases 3-6, it increased by at least $1.0+$ (Tables 4 and 9), which equals the highest change observed over time in controls (Table 2). The changes in controls were decrements, not increments, as in the present patients. There seemed to be interrelationship between pain side and side of most marked tendency to mechanical pain provocation (Table 4).

In cases 3, 4 and 5, there was a skin-fold thickness increment between examinations I and II, possibly most marked on the pain side (case 3 : borderline change, but still an increment). In cases 4 and 6 , the final thickness was increased (Tables 2 and 4). As skinfold thickness was unmeasurable on examination $\mathrm{I}$, it is unknown whether there was an increment after whiplash in case 6 also. Skin tenderness increased in one case (Table 9). Tenderness seemed to increase also in the other cases, but not enough to have a definite impact on the scores.

In three cases, there seemed to be a deterioration in ROM (Tables 4 and 7); in two, a rather clear deterioration and in one, case 6 , only a marginal one. Reduction in ROM mostly concurred with a clinical deterioration; but clinical deterioration also co-existed with insignificant changes in rotation (case 5).

The control ROM values for each whiplash case seemed to exceed the examination I values slightly (Table 4). In headache-free individuals in Vågå $(n=246)$, a mean rotation deficit of $6.2^{\circ}$ was observed (Table 2 ), but the range was considerable: $0^{\circ}-75^{\circ}$. This complicates the assessment of ROM, as detailed in Tables 4 and 7. ROM changes - markedly - with age, e.g., $30 \%$ of 60-65-year-old headache-free parishioners have a rotation reduction of $>15^{\circ}$ in the Vågå series. Particularly in case 6 , assessment was hampered: an additional rotation reduction of $10^{\circ}$ may be within control limits, due to the age. The three oldest parishioners, i.e., cases 2, 3 and 6, did not have a marked reduction in rotation at the prewhiplash stage. 
Table 9 Difference between scores, examinations I and II

\begin{tabular}{|c|c|c|c|c|c|c|c|c|c|c|c|c|}
\hline \multirow{2}{*}{$\begin{array}{l}\text { Case } \\
\text { Pertinent variable }\end{array}$} & \multicolumn{2}{|c|}{1} & \multicolumn{2}{|c|}{2} & \multicolumn{2}{|c|}{3} & \multicolumn{2}{|c|}{4} & \multicolumn{2}{|c|}{5} & \multicolumn{2}{|l|}{6} \\
\hline & I & II & I & II & I & II & I & II & I & II & I & II \\
\hline \multicolumn{13}{|l|}{ Skin-roll test } \\
\hline Thickness & 0 & 0 & 0 & 0 & 0 & 0.5 & 0 & 0.5 & 0 & 0.5 & $?$ & 0.5 \\
\hline Tenderness & 0 & 0 & 0 & 0 & 0.5 & 0.5 & 0.5 & $0.5^{\mathrm{a}}$ & 0 & 0.5 & 0.5 & 0.5 \\
\hline$R O M$ & 0 & 0 & 0 & 0.5 & 0.5 & 1.0 & 0.5 & 1.0 & 0 & 0 & 0.5 & 0.5 \\
\hline \multicolumn{13}{|l|}{ Provocations } \\
\hline Muscles & 0.5 & 0.5 & 0 & 0 & 0.5 & 0.5 & 0.5 & 0.5 & 0 & 0.5 & 0 & 0.5 \\
\hline Tendons & 1.0 & 1.0 & 0 & 0 & 0 & 1.0 & 1.5 & 2.0 & 0 & 0.5 & 0.5 & 1.5 \\
\hline Facet joints & 0 & 0 & 0 & 0 & 0 & 0 & 0 & 0.5 & 0 & 0 & 0 & 0.5 \\
\hline Sum ("CF"): & 1.5 & 1.5 & 0 & 0.5 & 1.5 & 3.5 & 3.0 & 5.0 & 0 & 2.0 & $1.5(2.0 ?)^{\mathrm{b}}$ & 4.0 \\
\hline Difference, examinations: II-I & 0 & & 0.5 & & 2.0 & & 2.0 & & 2.0 & & 2.0 & \\
\hline
\end{tabular}

As regards transformation of actual measurements (from Tables 4 and 7) into +-es, see Methods

Both sides are considered together

aThere seemed to be a clear increment in tenderness and with a symptomatic side predominance; but the "extra" $0.5+$ of the grading system had already been used to characterise "tendons provocation"; b As no definite value was obtained for skin-fold thickness on examination I, the sum of "CF" on examination I could be $1.5+$ or $2.0+$. In the calculation of the mean difference between examinations II and I, the higher value $(2.0+)$ for examination I has been used

$R O M$, range of motion in the neck

When the values for the 5 subgroups of the CF (outlined in Table 2) were transformed from absolute values to +-es, examination II CF values ("sum") varied between $2.0+$ and $5.0+$ in the four, clinically affected, whiplash victims (mean 3.6+; Table 9). For comparison, a value $>3.0+$ was present in only $0.93 \%$ of the Vågå population [8] (Table 2). The mean increment, 2.0+, is a high value (Tables 2 and 9). The mean change over time in Vågå (Table 2) was $0.17+$ and the maximum, $1.0+$, in 3 of 39 cases (reduction in all) [8]. It is remarkable that the prewhiplash CF values, cases 3-6 (Table 9) were higher than in the population at large: mean $1.50+$ (range 0-3.0), vs. $0.79+$. The parameters: skin-roll test, ROM and CF did not necessarily change in concert.

\section{Case history}

One case history will be detailed - more or less in telegram style - to present a more coherent, individual picture, as opposed to the symptom-oriented pictures in the tables.

Case 3. From teenage, migraine without aura (seven out of nine IHS criteria [14]); 4-8 times a year, half-aday duration; 2-4+ intensity (up to moderately intense), on a $0-6+$ scale [18]; unilaterality of pain with changing side preponderance. Diminishing complaints, recent years. Analgesics: 3-4 times/year. No previous traumas; no neck complaints prior to the neck sprain. Examination I: reduced ROM; due to his age (58 years old), this is somewhat hard to evaluate (Tables 4, 9). Accident: rear-end collision (Tables 3, 5). After the accident: migraine attacks of the old brand, i.e., frontal and mostly right-sided location (Tables 3 and 6) could still occur, but only rarely and with lesser intensity. Photo- and phonophobia: not present any more. Considered himself "unhurt" right after accident. However, "new" headache already from next day (Table 6). Out of work, wholly/partly for several months. Stiffness neck: difficulties in backing car; headache provocation in various neck positions and during sleep. Short-term memory: reduced. Creativity/endurance/ capacity at job: considerably reduced. Operated for snoring at 45 , with recurrence from 50 . Some of the latter symptoms can be due to this recurrence. Analgesics: $\geq 1$ time per week, a 10-fold increase. New headache: bilateral from neck to the temporal area, and present approximately $50 \%$ of the time. Mild discomfort into arms upon coughing (?). The provocation mechanisms were new; the frequency and the location of headache had changed, but also the intensity of the attacks (Table 7). Moderate, but clear tendency to improvement over the last months. Examination II: a further, clear reduction in ROM; minor increment in skinfold thickness and a worsening as regards precipitation of pain from nuchal tendon insertions (Tables 4, 7, 9). Conclusion: Physical findings originating in the post-whiplash period, proba- 
bly indicative of neck involvement; combination with "new" headache.

\section{Discussion}

The significance of the changes observed after the trauma

In spite of the small number of patients, this study may seem to constitute evidence that whiplash trauma may be followed by exacerbation of existing headache or a de novo headache; there may be a corresponding derangement of pertinent, physical/neurological parameters. This combination of physical findings/headache appearance was only found in the four parishioners who felt that their situation had deteriorated. Without a system of measurements to semi-quantify the, changes, after all mostly moderate, they would probably not have been detectable: routine neurological examination would, for example, not have sufficed. If only one physical variable were used, like ROM, then not all the cases would have been detected either (Table 4). The provocation tests (Table 9) seem to be crucial in this context [21, 22]. The presently employed detection system [8,9] is coarse and could be refined. The changes observed by skin-fold measurements are likely to represent incontrovertible evidence. This study may outline a path to be followed in future whiplash research.

The situation may be even more problematic as regards the anamnestic information: there was a preexisting headache, which could even be of a similar type (cf. patient 4, Table 3, who sustained a first whiplash at 20, and with clearly the highest $\mathrm{CF}$ at examination I; Table 9). In a couple of them, there were even two preexisting headaches (Table 3). Does there then seem to be any reason for concern? The old headache(s) could explain it all. And this is when one is handling the patient personally. With questionnaires, the situation would be even more intricate. Can the changes observed in the present study have developed as the consequence of natural processes during the passage of time? Any deterioration after the whiplash trauma (post-whiplash) may not necessarily be due to the whiplash (propter whiplash). Conceivably, "degenerative changes", independent of the neck sprain, may have occurred before, as well as after, the neck sprain. Against this type of reasoning, the following features count: three parishioners were not in the "degenerative stage", the age at whiplash being 23, 26 and 36 years, respectively. Nevertheless, in two of them the increments exceeded the changes observed over time in controls (Tables 2 and 4). Moreover, the skin-roll test changes observed in controls were reductions (Table 2) and not increments as in the present group.

In Table 9, there are six variables, in that the skin-roll test has been divided into two parts: skin thickness and tenderness. In the two cases without de novo headache, there was an increment in only one solitary variable (ROM, case 2 ), i.e., in 1 of 12 variables, or $8 \%$. In those with increased headache complaints, among a total of 24 variables (i.e., $4 \times 6=24$ ), there were changes in 14 variables, i.e., in $58 \%$. In each of the four whiplash victims, there was a change concerning three or more variables (mean 3.5). There thus seemed to be a preponderance of organic changes in symptomatic cases after whiplash injury. The precipitation variables may not be independent; for that reason, we have chosen not to make a statistical comparison between those with and without sequelae.

The incidence of whiplash in Vågå may seem to conform well to that observed elsewhere, i.e., approximately 70 per 100000 per year [2, 23]. There are some peculiarities in the present series: the proportion of protracted headache, i.e., four of six, may at face value seem to be higher than expected. However, traditional, observational, epidemiological studies would probably not have detected any of these four cases. Possibly, the pre-existing migraine and $\mathrm{CEH}$ have played a predisposing role.

"Late whiplash syndrome" has been defined as symptoms lasting $>6$ months $[11,24]$. Only in case 4 had the headache become daily. There may, however, be another way of defining chronicity. As $\mathrm{CEH}$ diagnosis consists of two components (case history and clinical examination), normalcy could be defined as indicating return to status quo of both, not only of the subjective symptoms. There is some recent evidence that clinical "scars" can persist longer than the symptoms [25].

\section{Cervicogenic headache and neck trauma}

Cervicogenic headache $(\mathrm{CEH})$ as such was described in 1983 [21] and its characteristics outlined already then. The criteria were expounded later [22]. Pieces of clinical evidence have, gradually, contributed to a strengthening - and the acceptance - of the concept that headache may stem from the neck [26-29].

Two aetiological factors have been invoked in $\mathrm{CEH}$ : degenerative processes and trauma [30]. Degenerative processes can hardly explain a mean onset at 23 years (range: 19-29), observed in a recent investigation [31], where 11 of 14 patients $(79 \%)$ had sustained a - mostly indirect - neck trauma, prior to the development of $\mathrm{CEH}$. That particular series was highly selected: females with pregnancies after onset of CEH. Anyhow, the latter study 
provides relatively strong evidence against degenerative changes as a significant aetiological factor, at least in some CEH cases. The Oslo whiplash study [25] furnishes evidence for de novo headache after whiplash injury, i.e., in $3.4 \%$ of the cases, at 1 year. An intricate situation is, however, apparent. Headache is ubiquitous: according to Pereira Monteiro [20], headache occurs occasionally/chronically in $89 \%$ of the population. The challenge may, therefore, amount to demonstrating that a headache present months after whiplash is a de novo headache, on top of a persisting, old headache.

A CEH - or perhaps a CEH-like headache - may seem not infrequently to follow in the wake of neck sprain. Such headache has, nevertheless, been described as a "tension-like" pain. This was the case in $74 \%$ of the cases in one study [32], where "identifiable", post-traumatic migraine \pm aura was present in $10 \%$. Also other observers conclude that this headache is a migraine $[33,34]$.

Are the CEH criteria [13, 22] fulfilled in the present whiplash victims?

In the present study, a meticulous physical/neurological examination was performed in each patient. It is probably a major advantage that the same investigator (OS) carried out both investigations. To the best of our knowledge, no such study has been carried out previously. The ideal situation: a clinical examination - by a headache expert - and a MRI study of the neck just ahead of the accident, and in a sizeable group at that, can theoretically be achieved, but will be close to impossible to engineer.

Precipitation mechanisms were present in all four (both neck movements and external iatrogenic pressure). Unilaterality without side shift is a cardinal feature of $\mathrm{CEH}$; but unilaterality on two sides may also occur in CEH [23]. The latter situation may seem to exist in case 3 (Tables 4 and 6). Bilaterality may not infrequently occur in whiplash [25]. With this provision, all the, purely clinical, CEH criteria, but one (ROM, case 5) (or two?: ROM, case 6) seem to be fulfilled in the four headache-prone whiplash victims (Tables 4 and 8). ROM reduction is not an obligatory $\mathrm{CEH}$ phenomenon, in particular if precipitation mechanisms are present [22].

At the time of the Våga study, the existing criteria were those from 1990 [13]; these guidelines were, therefore, also followed during examination II. These criteria do not require blockades.
Previous approach to the problem

The high frequency of subjective complaints, i.e., in $67 \%$, a mean of 2.8 years after the neck sprain, may seem strange. However, others have obtained similar results, although mainly regarding neck pain. Thus, Norris and Watt [35] found neck pain in 66\% of their cases after approximately 2 years, and Borchgrevink et al. [36] found chronic complaints in $58 \%$ after 2.5 years. In other studies, however, a lower percentage was found: $29 \%$ [37] and 18\% [10]. Berglund et al. [5] found a difference of $25 \%$ between neck complaints in the exposed group and non-exposed control group. Such percentages to a high degree depend upon the sensitivity of the measuring standard used. Other studies have indicated a more favourable prognosis than in these series [e.g. 3, 39, 40]. The study designs have, however, been entirely different in various studies concerning the prognosis of neck sprain. The basis could be: e.g., all cases reported to a Motor Accidents Board, a statuary authority that recorded all such cases [11]; consecutively referred patients for medicolegal assessment of whiplash injury [1, 32]; participants in traffic accidents, gathered in aftertime from a Traffic Police Department registry [39]; individuals at the grass-roots level registered at a parochial health centre, none of the latter ones being involved in litigation processes (present study). It would be strange if these series from the outset consisted of a homogeneous type of individual. The techniques at examination also have varied vastly. Accordingly, one can hardly expect uniform results from these studies. Each of them may give "correct" results when taking the basis on which they arose into consideration. A detailed review of the various designs is outside the scope of the present communication. Suffice it to emphasise in this context that: the CEH diagnosis consists of two different elements, i.e., a careful anamnesis and a meticulous, clinical examination; and both elements are essential and non-separable, if a correct diagnosis is the aim. We are not familiar with a CEH diagnosis made "detached from the patient".

Acknowledgements We are indebted to GlaxoSmithKline of Norway, Pharmacia \& Upjohn and the Alf Harborg Foundation, Department of Neurology, St Olavs Hospital, Trondheim, Trondheim University Hospitals, for generous support during the various phases of the investigation. The authors are also grateful to the personnel at the Vågå Health Centre at Vågåmo for their aid. Last, but not least, we thank the inhabitants of the Vågå commune for their collaboration. 


\section{References}

1. Pearce JMS (2001) Headaches in the whiplash syndrome. Spinal Cord 39:228-233

2. Spitzer WO, Skovron ML, Salmi LR, Cassidy JD, Durancean J, Suissa S,

Zeiss E (1995) Scientific monograph on the Quebec Task Force on whiplash-associated disorders: redefining "whiplash" and its management. Spine 20[Suppl 8]:15S-73S

3. Schrader H, Obelieniene D, Bovim G, Surkiene D, Mickeviciene D, Miseviciene I, Sand T (1996) Natural evolution of the late whiplash syndrome outside the medicolegal context. Lancet 347:1207-1211

4. Teasell RW, Merskey H (1999) The Quebec Task Force on whiplash-associated disorders and the British Columbia Whiplash initiative: A study of insurance industry initiatives. Pain Res Manage 4:141-149

5. Berglund A, Alfredsson L, Cassidy JD, Jensen I, Nygren Å (2000) The association between exposure to a rear-end collision and future neck or shoulder pain: a cohort study. J Clin Epidemiol 53:1089-1094

6. Sjaastad O, Båtnes J, Haugen S (1999) The Vågå study; an outline of the design. Cephalalgia 19[Suppl 25]:24-30

7. Sjaastad O, Pettersen H, Bakketeig LS (2001) The Vågå study; epidemiology of headache I: the prevalence of ultrashort paroxysms. Cephalalgia 21:207-215

8. Sjaastad O, Fredriksen TA, Petersen HC, Bakketeig LS (2003) "Features indicative of cervical abnormality". A factor to be reckoned with in clinical headache work and research? Funct Neurol 18:195-203

9. Sjaastad O, Petersen HC, Bakketeig LS (2003) Skin-roll test. Skinfold thickness and reproducibility of the method. Vågå study. J Headache Pain 4:103-110

10. Radanov B, Sturzenegger M, DiStefano G (1995) Long-term outcome after whiplash injury. A 2-year follow-up considering features of injury mechanism and somatic, radiologic, and psychosocial findings. Medicine 74:281-297
11. Balla J, Iansek R (1988) Headaches arising from disorders of the cervical spine. In: Hopkins A (ed) Headache. Problems in diagnosis and management. Saunders, Philadelphia, pp 241-267

12. Headache Classification Subcommittee of The International Headache Society (2004) The International Classification of Headache Disorders, 2nd edn (ICHDII). Cephalalgia 24[Suppl 1]:1-160

13. Sjaastad O, Fredriksen TA, Pfaffenrath V (1990) Cervicogenic headache: diagnostic criteria. Headache 30:725-726

14. Classification Committee of the International Headache Society (1988) Classification and diagnostic criteria for headache disorders, cranial neuralgias, and facial pain. Cephalalgia 8[Suppl 7]:1-96

15. Bansevicius D, Pareja JA, Sjaastad O (1997) "Skin roll" test ("pinch and roll") test: skinfold tenderness. Headache 37:281-285

16. McCain G (1993) The clinical features of the fibromyalgia syndrome. In: Værøy H, Merskey H (eds) Progress in fibromyalgia and myofascial pain. Elsevier, Amsterdam, pp 195-215

17. Merskey H, Bogduk N (1994) Classification of chronic pain. IASP Press, Seattle

18. Sjaastad O, Fredriksen TA, Petersen HC, Bakketeig LS (2002) Grading of headache intensity. A proposal. J Headache Pain 3:117-127

19. Bovim G, Schrader H, Sand T (1994) Neck pain in the general population. Spine 19:1307-1309

20. Pereira Monteiro JM (1995) Cefaleias. Estudo epidemiologico e clinico de uma população urbana. Thesis, Porto

21. Sjaastad O, Saunte C, Hovdal H, Breivik H, Grønbæk E (1983) "Cervicogenic" headache. An hypothesis. Cephalalgia 3:249-256

22. Sjaastad O, Fredriksen TA, Pfaffenrath V (1998) Cervicogenic headache. Diagnostic criteria. Headache 38:442-445
23. Rø M, Borchgrevink G, Dæhlie B, Finset A, Lilleås F, Laake K, Nyland H, Loeb M (2000) Nakkeslengskade. Diagnostikk og evaluering. Metodevurdering basert på egen litteraturgransking. SMM-rapport nr. 5; SINTEF/UNIMed, Oslo

24. Stovner LJ (1996) The nosologic status of the whiplash syndrome: a critical view based on a methodological approach. Spine 21: 2735-2746

25. Drottning M, Staff P, Sjaastad O (2004) Cervicogenic headache (CEH) in a whiplash cohort. In: Drottning $\mathrm{M}$ (ed) Proceedings from the 1st international conference of cervicogenic headache and whiplash, p 10

26. van Suijlekom JA (2001) Cervicogenic headache. Thesis. University of Maastricht. Formaris BV, Maastricht ISBN 90-9014845-0

27. Sjaastad O, Bakketeig LS (2002) Tractor drivers' head- and neck-ache. Vågå study of headache epidemiology. Cephalalgia 22:462-467

28. Sjaastad O, Stolt-Nielsen A, Blume H, Zwart J-A, Fredriksen TA (1995) Cervicogenic headache. Long-term results of radiofrequency treatment of the planum nuchale. Funct Neurol 10:265-271

29. Fredriksen TA, Stolt-Nielsen A, Skaanes K, Sjaastad O (2002) Headache and the lower cervical spine: long-term, postoperative follow-up after decompressive neck surgery. Funct Neurol 18:17-28

30. Bärtschi-Rochaix W (1949) Migraine cervicale. Hans Huber, Bern

31. Sjaastad O, Fredriksen TA (2002) Cervicogenic headache: lack of influence of pregnancy. Cephalalgia 22:667-671

32. Foletti G, Regli F (1995) Caractéristiques des céphalées chroniques après entorse cervicale. Presse Med 24:1121-1123

33. Weiss H, Stern B, Goldberg J (1991) Post-traumatic migraine: chronic migraine precipitated by minor head or neck trauma. Headache 31:451-456

34. Winston KR (1987) Whiplash and its relationship to migraine. Headache 27:452-457

35. Norris SH, Watt I (1983) The prognosis of neck injuries resulting from rear-ends vehicle collisions. J Bone Joint Surg Br 65:608-611 
36. Borchgrevink GE (1997) Diagnosis and treatment of whiplash/neck sprain injuries caused by car accidents.

Thesis, Trondheim University NTNU, Tapir, Trondheim

37. Hildringsson C, Toolanen G (1990) Outcome after soft-tissue injury of the cervical spine. A prospective study of 93 car-accident victims. Acta Orthop Scand 61:357-359
38. Schrader H, Stovner LJ, Ferrari R (2002) Chronic whiplash syndrome an overview. Tidsskr Nor Lægeforen 122:1296-1299
39. Obelieniene D (1998) Epidemiology of whiplash associated disorders in Kaunas city, Lithuania. Thesis,

Kaunas Medical University, Medical University Press, Kaunas 